\title{
REVIEW
}

\section{Brain death and the cervical spinal cord: a confounding factor for the clinical examination}

\author{
AR Joffe, N Anton and J Blackwood \\ Department of Pediatrics, Stollery Children's Hospital, University of Alberta, Edmonton, Alberta, Canada
}

\begin{abstract}
Study design: This study is a systematic review.
Objectives: Brain death (BD) is a clinical diagnosis, made by documenting absent brainstem functions, including unresponsive coma and apnea. Cervical spinal cord dysfunction would confound clinical diagnosis of BD. Our objective was to determine whether cervical spinal cord dysfunction is common in BD.

Methods: A case of BD showing cervical cord compression on magnetic resonance imaging prompted a literature review from 1965 to 2008 for any reports of cervical spinal cord injury associated with brain herniation or BD.

Results: A total of 12 cases of brain herniation in meningitis occurred shortly after a lumbar puncture with acute respiratory arrest and quadriplegia. In total, nine cases of acute brain herniation from various non-meningitis causes resulted in acute quadriplegia. The cases suggest that direct compression of the cervical spinal cord, or the anterior spinal arteries during cerebellar tonsillar herniation cause ischemic injury to the cord. No case series of brain herniation specifically mentioned spinal cord injury, but many survivors had severe disability including spastic limbs. Only two pathological series of BD examined the spinal cord; $56-100 \%$ of cases had upper cervical spinal cord damage, suggesting infarction from direct compression of the cord or its arterial blood supply.

Conclusions: Upper cervical spinal cord injury may be common after brain herniation. Cervical spinal cord injury must either be ruled out before clinical testing for BD, or an ancillary test to document lack of brainstem blood flow is required in all cases of suspected BD. BD may not be a purely clinical diagnosis.
\end{abstract}

Spinal Cord (2010) 48, 2-9; doi:10.1038/sc.2009.115; published online 8 September 2009

Keywords: brain death; apnea test; spinal cord injuries

\section{Introduction}

Death is said to occur when there is an irreversible loss of the integrative unity of the organism as a whole. ${ }^{1,2}$ Brain death (BD) is accepted in most countries of the world as death of the patient; ${ }^{3}$ this is because it purportedly shows that the supreme regulator of the body is dead, and therefore all that is left is a disintegrated corpse. ${ }^{1,2}$ It is said that BD is fundamentally a clinical diagnosis made at the bedside. ${ }^{4-7}$ Using medically standardized tests that examine functions of the brainstem, one can diagnose the irreversible state of $\mathrm{BD}$ at the bedside. Ancillary or confirmatory radiological or electrophysiological testing is not required unless there are confounding factors interfering with the clinical bedside tests. $^{4,6-8}$

Correspondence: Dr AR Joffe, Department of Pediatrics, 3A3.07 Stollery Children's Hospital, 8440112 Street, University of Alberta, Edmonton, Alberta, Canada T6C 2B7.

E-mail: ajoffe@cha.ab.ca

Received 16 June 2009; revised 16 July 2009; accepted 26 July 2009; published online 8 September 2009
The American Academy of Neurology writes that to diagnose $\mathrm{BD}$ there must be "exclusion of complicating medical conditions that may confound clinical assessment. ${ }^{7}$ They further write that the clinical examination of the brainstem includes testing of the brainstem reflexes, determination of the patient's ability to breath spontaneously, and the evaluation of motor responses (of the limbs) to pain...All clinical tests are needed to declare BD and are likely equally essential. (One should not prioritize individual brainstem tests). A confirmatory test is needed for patients in whom specific components of clinical testing cannot be reliably evaluated. ${ }^{9}$ Similarly, the Canadian Neuro-Critical Care Group wrote that there should be 'no movements... arising from the brain...no confounding factors for the application of clinical criteria...'; coma includes there being 'no spontaneous or elicited movements', and apnea testing is 'to ensure that an adequate stimulus is presented to the respiratory center (in the medulla). ${ }^{10}$ The more recent Canadian Forum wrote that minimum clinical criteria that must be present in 'brain arrest' include 'deep unresponsive 
coma with bilateral absence of motor responses... absent respiratory effort on the apnea test; absent confounding factors'; indeed, to do an ancillary test one must document 'deep unresponsive coma. ${ }^{4}$ High cervical spinal cord injury would be a confounding factor. ${ }^{11}$ Other authors have written that the clinical testing to diagnose BD is done to show 'cerebral unresponsivity'; 'absence of the brainstem functions $^{\prime 12}$ and 'loss of brainstem function; and signifies that breath as an essential element of life has vanished from man; ${ }^{13}$ or 'loss of the breath of life. ${ }^{\text {'14 }}$

We present a case and review the literature to argue that bedside testing cannot diagnose $\mathrm{BD}$, because the cervical spinal cord is often injured and dysfunctional after cerebellar herniation, and therefore is a confounding factor. A test that can differentiate lower brainstem irreversible loss of function from upper cervical spinal cord loss of function should be required, if the criterion of $\mathrm{BD}$ and the diagnostic standards for it are to be taken seriously.

\section{Case report}

An 11-year-old boy had a history of months of morning vomiting, headaches, lethargy, weight loss, and weeks of ataxia and nystagmus. He presented with acute onset of coma, and was intubated, hyperventilated, given mannitol, started on an infusion of hypertonic saline and had an urgent external ventricular drain inserted. Computed-tomographic scan before the ventricular drain showed acute hydrocephalus with a posterior fossa mass. Magnetic resonance imaging (MRI) after the ventricular drain showed severe cerebellar tonsillar herniation with displacement of the upper cervical spinal cord (Figure 1a), and injury of the first cervical spinal cord segment (Figure 1b). Repeated clinical testing was compatible with $\mathrm{BD}$; however, because of the MRI cervical spinal cord findings we did a 99mTc-ethyl cysteinate dimer planar radionuclide blood flow test that documented no uptake in the cerebrum or cerebellum (Figure 2). The family consented to organ donation, which was done.

\section{Materials and methods}

This case prompted us to question whether cervical spinal cord injury may be a common confounding factor in diagnosing BD. As MRI is only rarely done in suspected BD, cervical spinal cord involvement would rarely be identified in usual practice. We searched MEDLINE and PubMed from 1965 to 2008 with any combination of the following search terms: intracranial hypertension, quadriplegia, spinal cord injuries, spinal cord compression, tentorial herniation, uncal herniation and brain herniation. All abstracts were reviewed, and potentially relevant publications retrieved. Reference lists of relevant publications were also reviewed and potentially relevant publications retrieved. Any report mentioning quadriplegia, spinal cord injury or spinal cord compression in the setting of intracranial hypertension or brain herniation was considered potentially relevant. We also searched MEDLINE and PubMed from 1965 to 2008 for
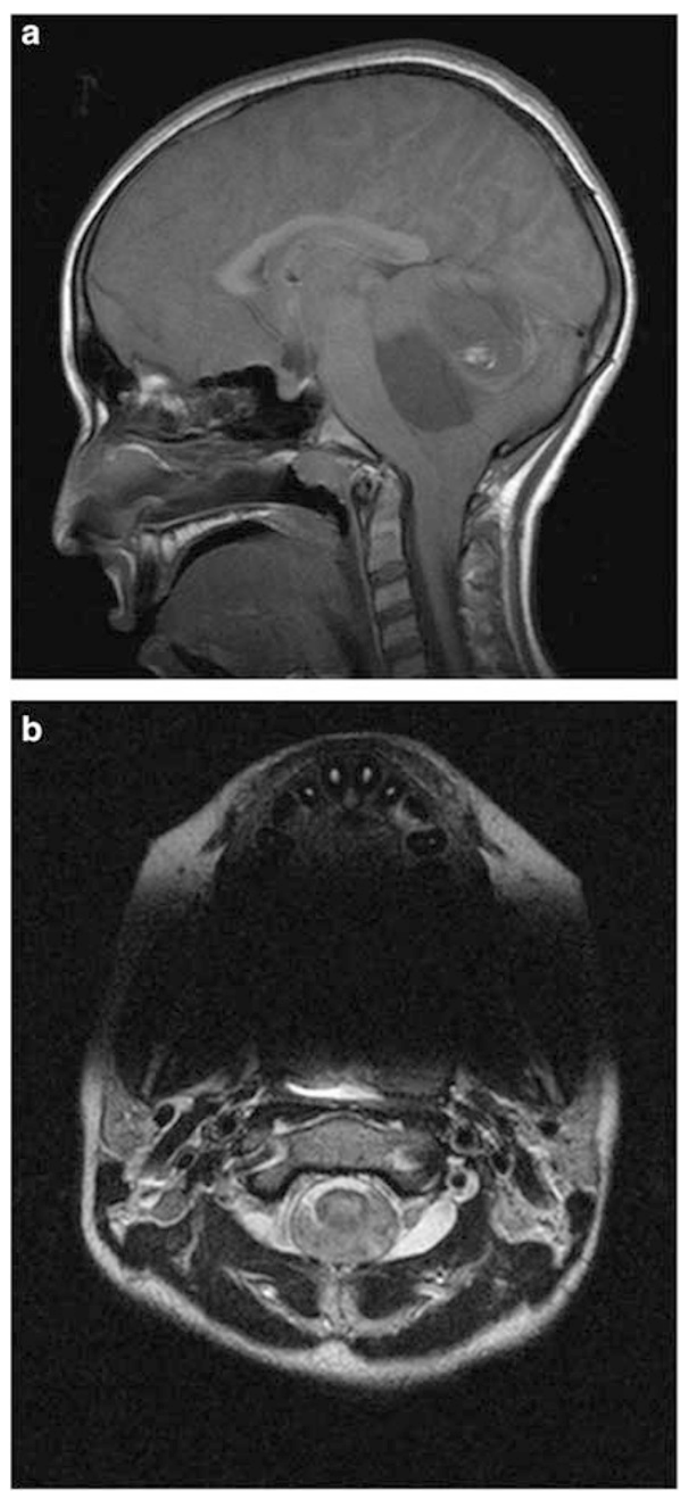

Figure 1 Magnetic resonance imaging (MRI) scans of the brain showing cerebellar tonsillar herniation through the foramen magnum into the cervical spinal canal with (a) sagittal T1-weighted image showing displacement of the upper cervical spinal cord, and (b) axial T2-weighted image through the level of the first cervical spinal segment showing hyperintense signal within the substance of the spinal cord consistent with injury, and associated anterior displacement by the cerebellar tonsils. The MRI scan did not image below this level.

BD and pathology, and retrieved relevant publications. Any report of spinal examination postmortem was considered potentially relevant, retrieved, and the reference lists were also reviewed.

\section{Results}

We identified 12 cases reported of brain herniation during meningitis that resulted in quadriplegia (Table 1). ${ }^{15-25}$ These reports have remarkable similarities: a patient with 

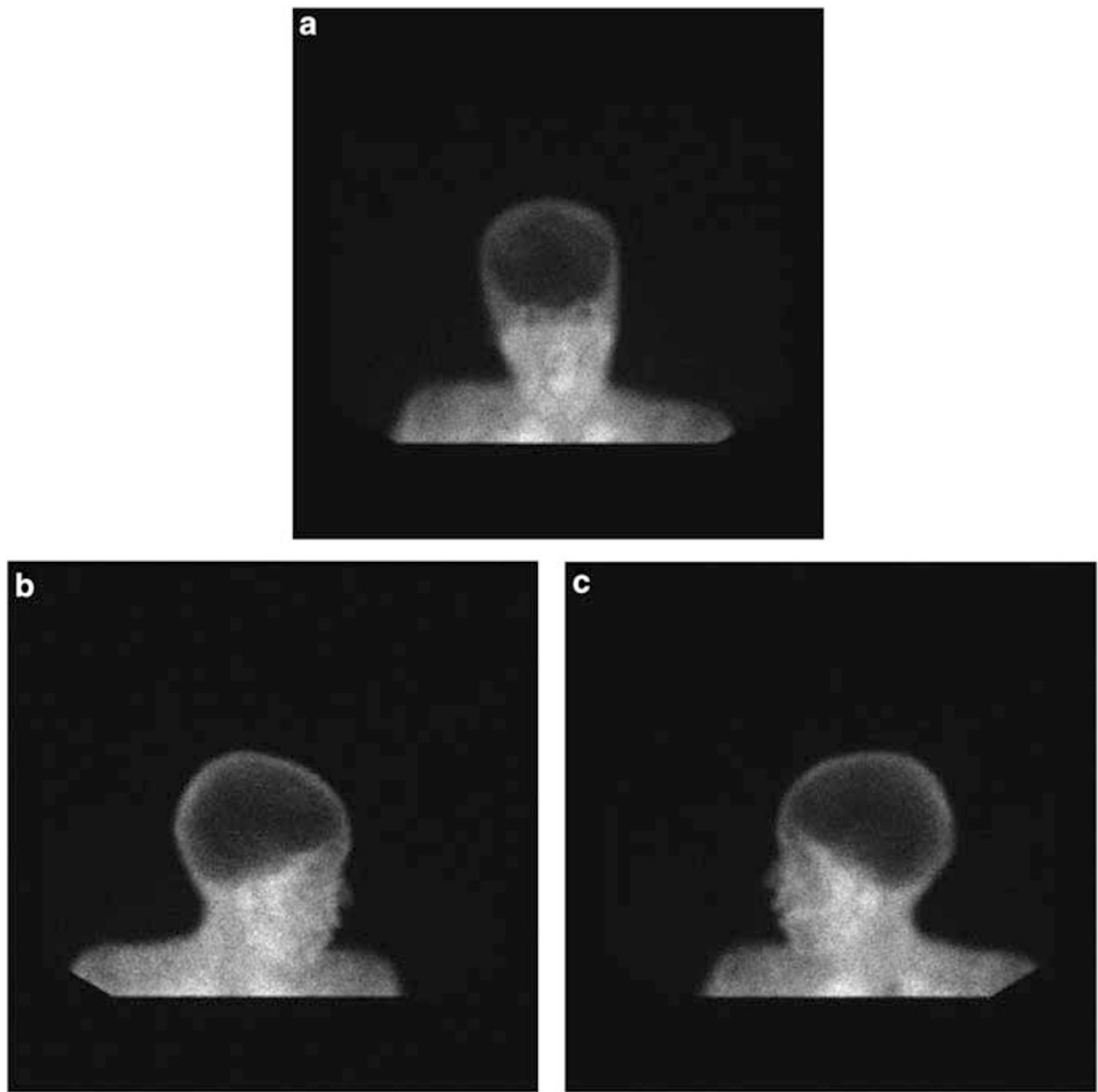

Figure 2 The $99 \mathrm{mTc}$-ethyl cysteinate dimer brain blood flow study showing lack of uptake of tracer in (a) the cerebral hemispheres on the static anterior view, and (b and c) cerebral and cerebellar hemispheres on the static lateral views.

an altered level of consciousness has a lumbar puncture, and shortly thereafter has a respiratory arrest followed by high cervical spinal cord quadriplegia with variable partial later recovery. Two cases died and autopsy showed infarction of the upper cervical cord without evidence of arachnoiditis. ${ }^{19,24}$ Three cases had MRI and this showed swelling or compression of the upper cervical spinal cord. ${ }^{23-25}$ Several of the reports specifically mention that the findings were compatible with anterior spinal artery compression resulting in high cervical spinal cord injury. ${ }^{15,17,19}$

We identified nine cases reported of brain herniation without meningitis that resulted in quadriplegia (Table 2). ${ }^{26-28}$ Six cases had sudden brain herniation and a respiratory arrest, four of these shortly after a lumbar puncture. These cases at autopsy had upper cervical spinal cord necrosis (four) or tense spinal dura (two) most likely due to 'compression of the spinal cord and possibly compromise of its vascular supply by the large amounts of displaced cerebellar tissue. ${ }^{26}$ Three cases had sudden brain herniation from acute hydrocephalus and later variable partial recovery. ${ }^{27,28}$ These three cases at MRI had evidence of cord edema or infarction, and the pathophysiology was hypothesized to be due to arterial (anterior spinal artery) insufficiency because of brain herniation (the vessels 'descend through the foramen magnum after taking off from the vertebral arteries intracranially ${ }^{28}$ ), and direct spinal cord compression with local ischemia and venous obstruction. ${ }^{27,28}$

There were some case series that reported outcomes after brain herniation (Table 3). ${ }^{29-35}$ Unfortunately, none of these specifically commented on whether the outcomes in survivors were due to spinal cord injury. These series show that there is a high mortality after brain herniation, and that $25-50 \%$ of survivors are left with severe sequelae, including 'spastic limbs. ${ }^{29-35}$ In one series of traumatic transtentorial herniation, cardiac arrest, flaccidity or bilateral fixed pupils after the herniation predicted worse neurological outcome. ${ }^{33}$

We found only two case series of $\mathrm{BD}$ that specifically commented on the pathological findings in the spinal cord (Table 4). ${ }^{36-38}$ The Cerebral Survival Study, the only prospective study of $\mathrm{BD}$ ever reported, found that upper cervical spinal cord damage was present in 71/127 (56\%) of autopsies. ${ }^{36,37}$ In total, 54 cases had 'localized edema, necrosis, infarction or hemorrhage at the cervicomedullary junction,' and in another 17 cases 'acute and chronic neuronal changes, and glial alteration were present in the upper cervical spinal cord. ${ }^{36,37}$ The authors wrote that 'because this is the location of tonsillar herniations and the boundary of cerebral and spinal circulation, it is susceptible to the vascular changes produced by the cut-off of the vertebral blood supply which caused 'demarcating reaction' 


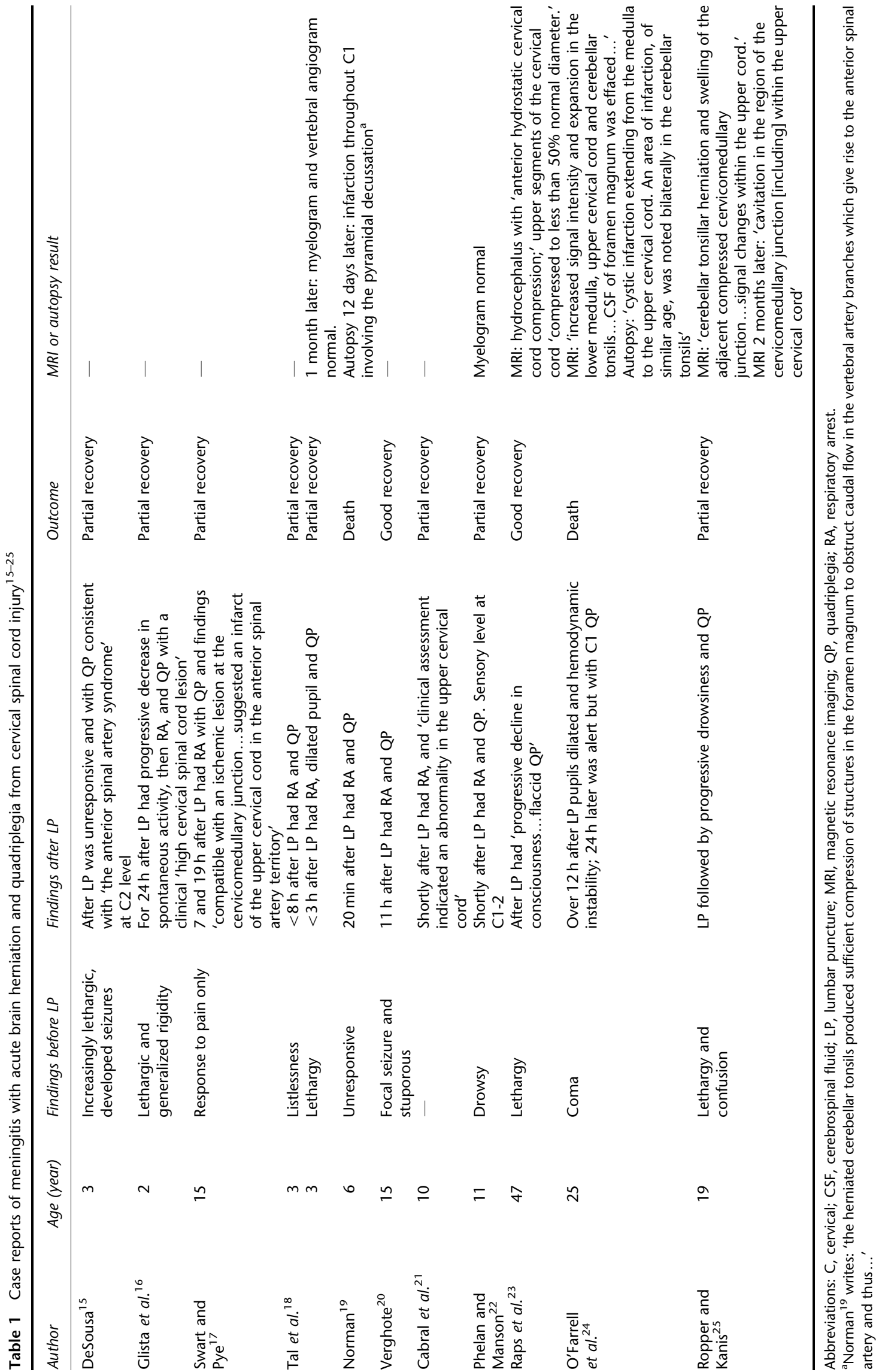


Table 2 Reports of non-meningitis cases of acute brain herniation and quadriplegia from cervical spinal cord injury ${ }^{26-28}$

\begin{tabular}{|c|c|c|c|c|c|}
\hline Author & Age (year) & Disease & Description & Outcome & Autopsy or MRI result \\
\hline \multirow[t]{6}{*}{$\begin{array}{l}\text { Herrick and } \\
\text { Agamandolis }^{26}\end{array}$} & 1 & Lead toxicity & $\begin{array}{l}\text { Lethargic, had LP, } \\
<9 \text { h later had RA }\end{array}$ & Death & Spinal dura tense \\
\hline & 12 & Reye syndrome & $\begin{array}{l}\text { Coma, had } L P \text {, } \\
\text { next day RA }\end{array}$ & Death & $\begin{array}{l}\text { Cervical necrosis of anterior posterior columns that } \\
\text { extended over most of the cervical enlargement }\end{array}$ \\
\hline & 7 months & Reye syndrome & $\begin{array}{l}\text { Coma, had LP, RA } \\
\text { next day }\end{array}$ & Death & Spinal dura distended and tense \\
\hline & 4 & Reye syndrome & $\begin{array}{l}\text { Seizures, LP, RA } \\
\text { later that day }\end{array}$ & Death & $\begin{array}{l}\text { Cervical cord compressed, distorted, with } \\
\text { vacuolated subpial white matter and necrosis } \\
\text { dorsal columns from cervical to upper thoracic } \\
\text { cord }\end{array}$ \\
\hline & 18 & Subdural empyema & $\begin{array}{l}\text { Coma, RA, } \\
\text { then LP }\end{array}$ & Death & $\begin{array}{l}\text { Upper cervical cord necrosis involving one dorsal } \\
\text { horn and adjacent dorsal column }\end{array}$ \\
\hline & 17 & Seizures and dialysis & $\begin{array}{l}\text { Clinical herniation } \\
\text { with RA }\end{array}$ & Death & $\begin{array}{l}\text { Cervical white matter vacuolated and fragmented } \\
\text { especially dorsal columns and adjacent lateral } \\
\text { columns }\end{array}$ \\
\hline \multirow[t]{2}{*}{$\begin{array}{l}\text { Sartoretti-Schefer } \\
\text { et } a .^{27}\end{array}$} & 53 & $\begin{array}{l}\text { Haemangioglastoma of } \\
\text { vermis with acute } \\
\text { hydrocephalus }\end{array}$ & Ataxic & $\begin{array}{l}\text { Alive with } \\
\text { recovery }\end{array}$ & $\begin{array}{l}\text { MRI: '.... cerebellar tonsils downward through } \\
\text { foramen magnum ....central grey matter and the } \\
\text { directly adjacent white matter showed diffuse high } \\
\text { signal on T2-weighted images, extending from C3 } \\
\text { to the upper margin of } C 7^{\prime}\end{array}$ \\
\hline & 19 & $\begin{array}{l}\text { Late postmeningitic adhesive } \\
\text { acute hydrocephalus }\end{array}$ & $\begin{array}{l}\text { Decreased level of } \\
\text { consciousness }\end{array}$ & $\begin{array}{l}\text { Alive with } \\
\text { recovery }\end{array}$ & $\begin{array}{l}\text { MRI: '... oedema was visible on T2-weighted } \\
\text { images in both cerebellar hemispheres and within } \\
\text { the grey matter and parts of the white matter of } \\
\text { the cervical spinal cord surrounding the dilated } \\
\text { central spinal canal' }\end{array}$ \\
\hline Siu et $a .^{28}$ & 24 & $\begin{array}{l}\text { Colloid cyst of third ventricle } \\
\text { with acute hydrocephalus }\end{array}$ & $\begin{array}{l}\text { Suddenly } \\
\text { unresponsive with } \\
\text { extensor } \\
\text { posturing and } \\
\text { then QP }\end{array}$ & $\begin{array}{l}\text { Partial } \\
\text { recovery }\end{array}$ & $\begin{array}{l}\text { MRI: 'abnormal signal change in the spinal cord } \\
\text { centrally extending from C4 to T3 and consistent } \\
\text { with a cord infarction...' }\end{array}$ \\
\hline
\end{tabular}

Abbreviations: C, cervical; LP, lumbar puncture; MRI, magnetic resonance imaging; QP, quadriplegia; RA, respiratory arrest; T, thoracic.

${ }^{a}$ Siu et al. ${ }^{28}$ write: the anterior spinal arteries 'descend through the foramen magnum after taking off from the vertebral arteries intracranially... would lead to distal watershed infarction in the thoracic region and with variable extension in a cephalad direction...'

Table 3 Case series of brain herniation describing outcomes suggestive of possible cervical spinal cord injury ${ }^{29-35}$

\begin{tabular}{|c|c|c|c|c|c|}
\hline Author & $\mathrm{n}$ & $\begin{array}{l}\text { Herniation } \\
\text { (n) }\end{array}$ & $\begin{array}{l}\text { Survivors of } \\
\text { herniation }(\mathrm{n})\end{array}$ & $\begin{array}{l}\text { Severe disability } \\
\text { in survivors ( } \mathrm{n} \text { ) }\end{array}$ & Comments \\
\hline \multicolumn{6}{|l|}{ Meningitis case series } \\
\hline Horwitz et al. ${ }^{29}$ & 302 & 18 & 15 & 4 & $\begin{array}{l}2 / 15(13 \%) \text { survivors of herniation had 'severe residua,' with } \\
\text { 'severe spastic hemiparesis' }\end{array}$ \\
\hline Rosenberg et al. ${ }^{30}$ & 453 & 16 & 4 & 1 & Spastic quadriplegia and late death in $1 / 4(25 \%)$ survivors \\
\hline Rennick et $a .^{31}$ & 445 & 19 & 5 & 2 & $2 / 5(40 \%)$ survivors of herniation with 'severe neurologic impairment' \\
\hline Pfister et $a l^{32}$ & 86 & 7 & 2 & 1 & $1 / 2(50 \%)$ survivors of herniation with 'spastic limbs' \\
\hline \multicolumn{6}{|c|}{ Traumatic head injury case series } \\
\hline Andrews and Pitts ${ }^{33}$ & 153 & 153 & 49 & 16 & $\begin{array}{l}14 \text { good recovery, } 14 \text { moderate disability, } 15 \text { severe disability } \\
\text { and } 1 \text { vegetative survivor. Cardiac arrest, flaccidity or bilateral } \\
\text { fixed pupils predicted worse outcome }\end{array}$ \\
\hline Aarabi et al. ${ }^{34}$ & 323 & Minority & $?$ & $>29.4 \%$ & $\begin{array}{l}\text { All had decompressive craniectomy: } 22.3 \% \text { death; } 29.4 \% \text { severe } \\
\text { disability or vegetative; } 48.3 \% \text { GOS of } 4-5\end{array}$ \\
\hline Salvatore et al. $^{35}$ & 80 & 80 & 68 & 8 & $\begin{array}{l}10 \% \text { severe disability; } 20 \% \text { moderate disability and } 55 \% \text { full recovery } \\
\text { with decompressive craniectomy. If decompressive surgery } \\
\text { delayed }>6 \mathrm{~h}, 16 \% \text { severe disability; } 21 \% \text { moderate disability, } \\
\text { and } 42 \% \text { full recovery }\end{array}$ \\
\hline
\end{tabular}

Abbreviation: GOS, Glasgow Outcome Score.

consisting of localized edema and laceration associated with petechial hemorrhages in the substance of the spinal cord. $^{36,37}$ Similarly, Schneider and Matakas ${ }^{38}$ found in a consecutive series of 15 cases 'if the organism is kept alive, it reacts in all cases identically... demarcation develops in the anterior pituitary lobe, in the upper cervical segments of the spinal cord.' There was hemorrhagic necrosis of C1-C3/4 shown by necrosis in 11 cases, and discoloration and softening in 4 cases. $^{38}$ These authors wrote that the cervical cord is 'supplied by arteries, arising from the intracranial portion of the vertebral arteries...it corresponds to the marginal area of an ischemic infarction. ${ }^{38}$ Other possible 
Table 4 Pathology series of brain death that include examination of the spinal cord $^{36-38}$

\begin{tabular}{|c|c|c|c|c|}
\hline Author & $\mathrm{n}$ & $\begin{array}{l}\text { Cervical spinal } \\
\text { cord abnormal (n) }\end{array}$ & $\begin{array}{l}\text { Other spinal cord } \\
\text { abnormal }(\mathrm{n})\end{array}$ & Comments \\
\hline $\begin{array}{l}\text { Walker et al. }{ }^{36} \text { and } \\
\text { Walker }^{37}\end{array}$ & 127 & $71(56 \%)^{\mathrm{a}}$ & 51 & $\begin{array}{l}\text { 54: localized edema, necrosis, infarction or hemorrhage of the } \\
\text { cervicomedullary junction; } 17 \text { : acute and chronic neuronal } \\
\text { changes and glial alteration were present in the upper cervical } \\
\text { spinal cord }\end{array}$ \\
\hline Schneider and Matakas ${ }^{38}$ & 15 & $15(100 \%)$ & 15 & $\begin{array}{l}\text { Hemorrhagic necrosis of } \mathrm{C} 1-\mathrm{C} 3 / 4 \text { based on: necrosis in } 11 \text {, and } \\
\text { discoloration and softening in } 4\end{array}$ \\
\hline
\end{tabular}

Abbreviation: C, cervical.

${ }^{a}$ The report, in the section on spinal cord pathology, writes '...76 of the 127 cases in which spinal cord was examined were reported to be grossly normal. Microscopically, in many cases, the substance of the spinal cord appeared normal. However, in about one-third of the cases, pathological alterations such as edema (13.8\%), petechial hemorrhages (5.7\%), neurolysis of anterior horn cells (11.4\%) were noted... At the cervico-medullary junction, where the blood supply may be derived from either vertebral or spinal arteries, myelopathy in the form of localized edema, necrosis, infarction, or hemorrhage, was present in 54 cases... In an additional 17 cases, acute and chronic neuronal changes were seen on microscopic examination of the upper cervical cord'(Walker; ${ }^{37}$ pp37). Similarly, in another report it is written '54 cases had localized edema, necrosis, infarction, or hemorrhage at the cervico-medullary junction... In 17 additional cases, acute and chronic neuronal changes and glial alterations were present in the upper cervical spinal cord' (Walker et al.; ${ }^{36}$ pp 303). Therefore, cervical pathology occurred in $71 / 127$ $(56 \%)$ if the cervico-medullary junction is included, and in at least $51 / 127$ (40\%) if the cervico-medullary junction is not included.

etiologies that were hypothesized included 'hindrance of venous drainage' and 'cuff of necrotic cerebellar tissue compressing the spinal cord. ${ }^{38}$ Both pathological series note that other areas of the spinal cord can be affected by a different pathological process; specifically, necrotic cerebellar tissue that had sedimented, causing inflammatory reaction in the marginal areas of spinal white matter of various parts of the spinal cord. ${ }^{36-38}$ Schroder did not describe detailed spinal cord pathology but in his series wrote, 'these [brain pathology] alterations decreased... caudal (lower medulla, first cervical segment), implying some changes in the upper cervical spinal cord. ${ }^{39}$

\section{Discussion}

Brain death is said to be fundamentally a clinical diagnosis at the bedside. ${ }^{4-7}$ Only when confounding factors make the clinical examination of brainstem functions unreliable is an ancillary test required. ${ }^{4-11}$ We report a case, and review the literature, to make the suggestion that upper cervical spinal cord injury is a common result of brain herniation, and a confounding factor in the clinical examination for BD. If unresponsive coma could be partly accounted for by the lack of ability to move the limbs, and if apnea could be attributed to absent respiratory muscle function, both due to upper cervical spinal cord injury, then clinical testing for BD is unreliable. ${ }^{11}$ Many case reports in the setting of sudden brain herniation both with and without meningitis show that permanent or partially reversible cervical spinal cord injury can occur, and the clinical, autopsy and MRI findings suggest this is due to direct compressive injury to the spinal cord, its arterial supply and its venous drainage. ${ }^{15-28}$ Furthermore, the autopsy series of BD show that high cervical spinal cord injury is a common finding (56-100\% of cases), and most likely due to compression of the upper cervical spinal cord and its blood supply during cerebellar herniation. ${ }^{36-38}$ This is compatible with early pathological reports of BD in other languages that found necrosis of the upper cervical segments of spinal cord, ${ }^{40,41}$ and with early cat and baboon animal models of $\mathrm{BD}$ showing demarcation at the $\mathrm{C} 1 / \mathrm{C} 2$ cord segments. ${ }^{42}$

If cervical spinal cord injury is common after cerebellar herniation, one could argue that there should be more reports of this phenomenon. There are several possible reasons to believe that this is not a sound argument. First, death usually occurs so quickly after herniation that quadriplegia is likely not recognized. ${ }^{19,28}$ Second, when quadriplegia is suspected after herniation, it is likely attributed to concomitant brainstem insult and followed by death. ${ }^{19,28}$ Third, severe sequelae in survivors of herniation are common, and likely attributed to other brain or brainstem injuries, without investigation of the cervical spinal cord. ${ }^{29-35}$ Fourth, in the setting of suspected BD, the spinal cord is rarely investigated or suspected to be affected when testing for limb movement to pain or apnea. ${ }^{4-11} \mathrm{~A}$ final reason is that most patients are imaged with a CT scan of the brain, and this is often not adequate to show cerebellar herniation, and not inclusive of the upper cervical spinal cord. ${ }^{43,44}$ To adequately show tonsillar herniation an MRI scan is required, and this is usually not done due to the hemodynamically unstable state of the patient. ${ }^{43-45}$

One could argue that some of the spinal cord injury cases could be due to spinal arachnoiditis with vasculitis in the setting of meningitis. There are several cases reported of spinal cord injury in meningitis due to this mechanism, proven at laminectomy or myelogram. ${ }^{46-52}$ These cases are different from the ones reported here. The cases reported usually occurred later in the meningitis course, were not associated with sudden respiratory arrest, were not shortly after a lumbar puncture, and involved lower parts of the spinal cord from C5 and lower. ${ }^{46-52}$ We found three cases of high cervical spinal cord injury in meningitis likely due to arachnoiditis: a 24-week premature neonate with meningitis who at 7 days of treatment became flaccid below the neck despite being awake and having spontaneous movements; a 33-week premature neonate with meningitis who at 4 days of treatment became flaccid and areflexic despite grimacing to pain, and autopsy showed extensive necrosis of the cervical spinal cord with exudates and vasculitis; and a neonate with 
meningitis who at 4 days of treatment was noted to be areflexic with minimal movement of the upper extremities and no movements of the lower extremities but was extubated 3 days later. ${ }^{50}$ These cases do not resemble the cases discussed here of sudden herniation with respiratory arrest and quadriplegia, and they do not explain the findings in the non-meningitis cases. Banks and McCartney ${ }^{46}$ in 1942 noted this when they described a variant of meningococcal meningitis that they called 'focal encephalomyelitis,' where there was sudden fatal collapse and pathological changes 'usually about the basal ganglia, midbrain, medulla, or upper cord...postmortem no satisfactory cause of death may be found in these cases on macroscopic examination, since the meningitis may have almost cleared up...it is only on careful histological examination...'.

It could also be argued that some of the cases of spinal cord injury may be due to the hypoxemia and ischemia of the respiratory arrest event. This mechanism would be expected to affect mostly the thoracic and lumbar spinal cord because the border zone of arterial circulation is in the thoracic cord. ${ }^{38,50}$ We note that, even if some cases of high cervical spinal cord injury are due to this mechanism, this still results in a confounding factor for the clinical examination for BD.

There are important implications of this discussion for the diagnosis of BD. First, we suggest that to clinically examine the brainstem functions of motor responses and respiratory drive, one must first know that upper cervical spinal cord injury is not a confounding factor. This may prove to be difficult because the sensitivity and specificity of MRI of the cervical spinal cord for this purpose is not known, and obtaining an MRI on all these potentially unstable and ventilated patients is difficult to manage and arrange. We are not aware of other tests, which could be used to prove that the upper cervical spinal cord is functioning. Whatever test is chosen, this makes the diagnosis of BD fundamentally not a clinical diagnosis until upper cervical spinal cord injury can be ruled out. It is interesting that this point is similar to the one made regarding the fact that brainstem damage is a confounding factor for the examination of cerebral functions in patients being assessed for BD. ${ }^{53}$

Second, if cervical spinal cord injury cannot be ruled out or is in fact present, another option may be to do an ancillary test to confirm that brainstem function is irreversibly lost. ${ }^{54}$ The absence of blood flow to the brainstem would likely show that the brainstem has died, regardless of cervical spinal cord function. This is problematic for several reasons. No radionuclide test, including HMPAO-SPECT, is known to diagnose brainstem death in isolation. ${ }^{6,8,55}$ High resolution HMPAO-SPECT may be capable of defining brainstem blood flow, ${ }^{56}$ but larger numbers of cases would be required to validate this test. In a recent review, it was found that for clinically confirmed BD the specificity of HMPAO-SPECT was 12/12 (100\%) (95\% CI 78.4-100\%), and for contrast angiography confirmed BD the specificity of HMPAO-SPECT could not be estimated, as there were no patients without clinical BD having both tests. ${ }^{57} \mathrm{~A}$ bilateral four-vessel internal carotid and vertebral artery angiogram may be required to show lack of blood flow to the brain and brainstem. To do this on every case of suspected BD would be difficult, and in addition, the angiogram is invasive and has the potential to cause vasospasm and worsen the brain injury if $\mathrm{BD}$ has not yet occurred. ${ }^{58}$ Moreover, we are not aware of a study showing that an angiogram can prove brain circulatory arrest and rule out residual brain blood flow enough to sustain some brain viability. Indeed, it has been shown that electroencephalographic activity can remain in cases with clinical BD and absent flow on four-vessel angiography; this suggests that the angiogram did not rule out residual blood flow sustaining viability of parts of the brain. ${ }^{59,60}$ Another study found that $13 / 43(30 \%)$ of clinically brain-dead patients with absent conventional angiographic brain blood flow had persistent cerebral perfusion by computed-tomographic angiography. ${ }^{61}$

In conclusion, this review suggests a major limitation in our ability to diagnose BD clinically at the bedside. Further expert discussion is needed to resolve this difficult issue.

\section{References}

1 President's Commission for the Study of Ethical Problems in Medicine and Biomedical and Behavioral Research. Defining Death: Medical, Legal and Ethical Issues in the Determination of Death. US Government Printing Office: Washington, DC, 1981.

2 Bernat JL, Culver CM, Gert B. On the definition and criterion of death. Ann Intern Med 1981; 94: 389-394.

3 Wijdicks EFM. Brain death worldwide: accepted fact but no global consensus in diagnostic criteria. Neurology 2002; 58: 20-25.

4 Shemie SD, Doig C, Dickens B, Byrne P, Wheelock B, Rocker G et al. Severe brain injury to neurological determination of death: Canadian forum recommendations. CMAJ 2006; 174: S1-S12.

5 Guidelines for the determination of death. Report of the Medical Consultants on the diagnosis of death to the President's commission for the study of ethical problems in medicine and biomedical and behavioral research. JAMA 1981; 246: 2184-2186.

6 Heran MKS, Heran HS, Shemie SD. A review of ancillary tests in evaluating brain death. Can J Neurol Sci 2008; 35: 409-419.

7 Report of the Quality Standards Subcommittee of the American Academy of Neurology. Practice parameters for determining brain death in adults (summary statement). Neurology 1995; 45: 1012-1014.

8 Shemie SD, Lee D, Sharpe M, Tampieri D, Young B, on behalf of the participants in the expert consensus meeting on brain blood flow in the neurological determination of death. Brain blood flow in the neurological determination of death: Canadian expert report. Can J Neurol Sci 2008; 35: 140-145.

9 Wijdicks EFM. Determining brain death in adults. Neurology 1995; 45: 1003-1011.

10 Canadian Neurocritical Care Group. Guidelines for the diagnosis of brain death. Can J Neurol Sci 1999; 26: 64-66.

11 Young GB, Shemie SD, Doig CJ, Teitelbaum J. Brief review: the role of ancillary tests in the neurological determination of death. Can J Anesth 2006; 53: 620-627.

12 Bernat JL. Brain death: occurs only with destruction of the cerebral hemispheres and the brain stem. Arch Neurol 1992; 49: 569-570.

13 Lang CJG, Heckmann JG. Apnea testing for the diagnosis of brain death: review article. Acta Neurol Scand 2005; 112: 358-369.

14 Pallis C. On the brainstem criterion of death. In: Youngner SJ, Arnold RM, Schapiro R (eds). The Definition of Death: Contemporary Controversies. The Johns Hopkins University Press: Baltimore, Maryland, 1999. pp 93-100.

15 DeSousa AL, Kleiman MB, Mealey Jr J. Quadriplegia and cortical blindness in Hemophilus influenzae meningitis. J Pediatr 1978; 93: 253-254.

16 Glista GG, Sullivan TD, Brumlik J. Spinal cord involvement in acute bacterial meningitis. JAMA 1980; 243: 1362-1363. 
17 Swart SS, Pye IF. Spinal cord ischaemia complicating meningococcal meningitis. Postgrad Med J 1980; 56: 661-662.

18 Tal Y, Crichton JU, Dunn HG, Dolman CL. Spinal cord damage: a rare complication of purulent meningitis. Acta Paediatr Scand 1980; 69: 471-474.

19 Norman MG. Respiratory arrest and cervical spinal cord infarction following lumbar puncture in meningitis. Can J Neurol Sci 1982; 9: 443-447.

20 Verghote M, Rousseau E, Geoffroy G. Quadriplegia after pneumococcal meningitis. Pediatr Infect Dis J 1985; 4: 559.

21 Cabral DA, Flodmark O, Farrel K, Speert DP. Prospective study of computed tomography in acute bacterial meningitis. J Pediatr 1987; 111: 201-205.

22 Phelan M, Manson JI. Spinal cord dysfunction with quadriplegia complicating pneumococcal meningitis. Aust Paediatr J 1987; 23: $57-59$.

23 Raps EC, Gutmann DH, Brorson JR, O'Connor M, Hurtig HI. Symptomatic hydrocephalus and reversible spinal cord compression in Listeria monocytogenes meningitis. J Neurosurg 1989; 71: 620-622.

24 O'Farrell R, Thornton J, Brennan P, Brett F, Cunningham AJ. Spinal cord infarction and tetraplegia- rare complications of meningococcal meningitis. Br J Anaesth 2000; 84: 514-517.

25 Ropper AH, Kanis KB. Flaccid quadriplegia from tonsillar herniation in pneumococcal meningitis. J Clin Neurosci 2000; 7: 330-345.

26 Herrick MK, Agamanolis DP. Displacement of cerebellar tissue into spinal canal: a component of respirator brain syndrome. Arch Pathol 1975; 99: 565-571.

27 Sartoretti-Schefer S, Kollias S, Valavanis A. Transient oedema of the cervical spinal cord. Neuroradiol 2000; 42: 280-284.

28 Siu TLT, Banna P, Stokes BAR. Spinal cord infarction complicating acute hydrocephalus secondary to a colloid cyst of the third ventricle. J Neurosurg Spine 2005; 3: 64-67.

29 Horwitz SJ, Boxerbaum B, O'Bell J. Cerebral herniation in bacterial meningitis in childhood. Ann Neurol 1980; 7: 524-528.

30 Rosenberg DI, McCrory JH, Abhoudon MK, Murante AA, Downs CE. Neuro-intensive care for cerebral herniation in childhood meningitis. In: Hoff JT, Betz AL (eds). Intracranial Pressure VII. Springer: Berlin, 1989. pp 770-772. (Proceedings of the seventh international symposium on intracranial pressure).

31 Rennick G, Shann F, de Campo J. Cerebral herniation during bacterial meningitis in children. BMJ 1993; 306: 953-955.

32 Pfister HW, Feiden W, Einhaupl KM. Spectrum of complications during bacterial meningitis in adults: results of a prospective clinical study. Arch Neurol 1993; 50: 575-581.

33 Andrews BT, Pitts LH. Functional recovery after traumatic transtentorial herniation. Neurosurgery 1991; 29: 227-231.

34 Aarabi B, Hesdorffer DC, Ahn ES, Aresco C, Scalea TM, Eisenberg HM. Outcome following decompressive craniectomy for malignant swelling due to severe head injury. J Neurosurg 2006; 104: 469-479.

35 Salvatore C, Marco M, Antonio R, Salvatore I, Eugenio B. Combined internal uncusectomy and decompressive craniectomy for the treatment of severe closed head injury: experience with 80 cases. J Neurosurg 2008; 108: 74-79.

36 Walker AE, Diamond EL, Moseley J. The neuropathological findings in irreversible coma: a critique of the 'respirator brain'. J Neuropathol Exp Neurol 1975; 34: 295-323.

37 Walker AE. Neuropathological findings in the brains of patients admitted to the collaborative study. In: Walker AE, Molinari GF, Bennett DR, Allen N (eds). The NINCDS Collaborative Study of Brain Death. US Department of Health and Human Services (NIH Publication No. 81-2286): Bethesda, Maryland, 1980. pp 33-76.

38 Schneider H, Matakas F. Pathological changes of the spinal cord after brain death. Acta Neuropathol 1971; 18: 234-247.
39 Schroder R. Later changes in brain death. Signs of partial recirculation. Acta Neuropathol 1983; 62: 15-23.

40 Ingvar DH. Brain death - total brain infarction. Acta Anaesth Scand Suppl 1971; 45: 129-140.

41 Liudkovskaia IG, Popova LM. Morphology and pathogenesis of 'brain death' in stroke. Arkh Patol 1978; 40: 48-54.

42 Matakas F, Cervos-Navarro J, Schneider H. Experimental brain death: 1. Morphology and fine structure of the brain. J Neurol Neurosurg Psychiatr 1973; 36: 497-508.

43 Ishikawa M, Kikuchi H, Fujisawa I, Yonekawa Y. Tonsillar herniation on magnetic resonance imaging. Neurosurgery 1988; 22: 77-81.

44 Reich JB, Sierra H, Camp W, Zanzonico P, Deck MDF, Plum F. Magnetic resonance imaging measurements and clinical changes accompanying transtentorial and foramen magnum brain herniation. Ann Neurol 1993; 33: 159-170.

45 Lee DH, Nathanson JA, Fox AJ, Pelz DM, Lownie SP. Magnetic resonance imaging of brain death. Can Assoc Radiol J 1995; 46: 174-178.

46 Banks HS, McCartney JE. Meningococcal encephalitis. Lancet 1942; 239: 219-223.

47 Turner JW. Spinal-cord lesions in cerebrospinal fever. Lancet 1948; 251: 398-402.

48 Haupt HM, Kurlinski JP, Barnett NK, Epstein M. Infarction of the spinal cord as a complication of pneumococcal meningitis. J Neurosurg 1981; 55: 121-123.

49 Seay AR. Spinal cord dysfunction complicating bacterial meningitis. Arch Neurol 1984; 41: 545-546.

50 Coker SB, Muraskas JK, Thomas C. Myelopathy secondary to neonatal bacterial meningitis. Pediatr Neurol 1994; 10: 259-261.

51 Puvabanditsin S, Wojkylo EW, Garrow E, Kalavantavanich K. Group B streptococcal meningitis: a case of transverse meyelitis with spinal cord and posterior fossa cysts. Pediatr Radiol 1997; 27: 317-318.

52 Moffett KS, Berkowitz FE. Quadriplegia complicating Escherichia coli meningitis in a newborn infant: case report and review of 22 cases of spinal cord dysfunction in patients with acute bacterial meningitis. Clin Infect Dis 1997; 25: 211-214.

53 Karakatsanis KG. Brain death: should it be reconsidered? Spinal Cord 2008; 46: 396-401.

54 Waters CE, French G, Burt M. Difficulty in brainstem death testing in the presence of high spinal cord injury. $\mathrm{Br} J$ Anaesth 2004; 92: 760-764.

55 Zuckier LS, Kolano J. Radionuclide studies in the determination of brain death: criteria, concepts, and controversies. Semin Nucl Med 2008; 38: 262-273.

56 Sviri GE, Lewis DH, Correa R, Britz GW, Douville CM, Newell DW. Basilar artery vasospasm and delayed posterior circulation ischemia after aneurysmal subarachnoid hemorrhage. Stroke 2004; 35: 1867-1872.

57 Joffe AR, Lequier L, Cave D. Specificity of radionuclide brain blood flow testing in brain death: case report and review. J Intensive Care Med 2009 (in press).

58 Kaufmann TJ, Huston III J, Mandrekar JN, Schleck CD, Thielen KR, Kallmes DF. Complications of diagnostic cerebral angiography: evaluation of 19826 consecutive patients. Radiology 2007; 243: 812-819.

59 Ashwal S, Schneider S. Failure of electroencephalography to diagnose brain death in comatose children. Ann Neurol 1979; 6: 512-517.

60 Paolin A, Manuali A, DiPaola F, Boccaletto F, Caputo P, Zanata R et al. Reliability in diagnosis of brain death. Intensive Care Med 1995; 21: 657-662.

61 Combes JC, Chomel A, Ricolfi F, d'Athis P, Freysz M. Reliability of computed tomographic angiography in the diagnosis of brain death. Transplant Proc 2007; 39: 16-20. 